Journal of Applied Finance \& Banking, Vol. 11, No. 6, 2021, 21-36

ISSN: 1792-6580 (print version), 1792-6599(online)

https://doi.org/10.47260/jafb/1162

Scientific Press International Limited

\title{
Factors Shaping Consumers Intention in Purchasing Life Insurance Policy in Bangladesh: A Binary Logistic Analysis
}

\author{
Md. Golam Ramij
}

\begin{abstract}
This paper investigates the demographic and socio-economic influential factors that work as a motivational tool for purchasing life insurance policies by the eligible consumers of Bangladesh. Using convenience sampling technique, responses of three hundred seventy-eight persons have been analyzed using this study's binary logistic regression model. This study found that demographic variables like age, education, and gender have no significant impact on life insurance policy buying decisions. On the contrary, the number of dependents in a family, nature of work, and monthly income positively impact the policy purchase decision. This study also reveals that insurance literacy has a positive influence, but acquired information about insurance policy negatively impacts consumers' purchasing decisions. In addition to that, the study's findings also show that people usually purchase a life insurance policy for tax benefit purposes instead of investment purposes. The outcomes of the study will be helpful to the insurers and policymakers to find out the major areas of improvement to bring more people under life insurance coverage, and for prospective consumers, it will guide them to understand the benefits of having a life insurance policy.
\end{abstract}

JEL classification numbers: C83, C93, H55, I13.

Keywords: Life insurance, Logistic model, Forecasting, Tax benefits, Agent.

${ }^{1}$ Lecturer, Department of Banking and Insurance, University of Dhaka.

Article Info: Received: September 19, 2021. Revised: October 6, 2021.

Published online: October 12, 2021. 


\section{Introduction}

Life insurance is a policy where the policyholders get assurance of a specified amount of money to be paid by the insurance company happening of a certain event (death/maturity) against regular premium payment. In a developing country like Bangladesh, healthcare facilities are not up to the mark. The per capita income recently touched more than $\$ 2000$, and GDP growth rate is more than $7 \%$. Bangladesh stepped into the middle-income earning country by 2030 and recently got recognition as a developing country from the least developing country. After achieving the MDG goal now, Bangladesh is fighting to achieve SDG (Sustainable Development Goal). One of the goals of SDG is ensuring better health care for everyone and ensuring financial inclusion. The life insurance facility can play a great contribution in achieving SDG within 2030 . The government is solely working on that. In Bangladesh, the insurance sector's contribution in GDP is less than .5\%, whereas, in India, it is more than 10\%. Thailand's average of 5.27 percent, Malaysia's 4.77 percent, China's 4.22 percent, Indonesia's 1.95 percent, and Sri Lanka's 1.15 percent (Abeda, 2019). It shows that South Asian countries are leveraging the benefits of insurance for growth and development (Ala Ahmad, 2021). So it can be said that the insurance sector is not flourished yet. In Bangladesh, there are seventy-seven life insurance companies, among which there are thirty-two life insurance companies. There is only one state-owned life insurance company and twenty-nine local private sector life insurance companies. There is only a foreign life insurance company (Bangladesh Bank, 2021).

Bangladesh is now called the emerging Asian Tiger, has drawn international attention in many stages of economic development. As the economy grows and the standard of living has improved, life insurance can play a crucial role in mitigating different vital risks associated with life by ensuring life assurance. Life insurance can also help achieve a sustainable goal by mobilizing long-term investment that helps scale up to large infrastructure and create more employment opportunities. The educated Bangladeshi people are competing in different global platforms by taking risks. Young entrepreneurs are improving their lifestyles by creating selfemployment arrangements for themselves and also for others (Ahmed, 2013). Experts say the key reasons why the life insurance industry in Bangladesh is performing unwell are mistrust, lack of awareness, negative publicity about companies, non-diversified products, unethical practice of the insurance agents, and lack of a strong monitoring system (Ali and Mahmud, 2021). But, the good news is that the regulatory body IDRA, (Insurance Development and Regulatory Authority) has taken strong initiative to improve the overall image of the country's insurance sector. The recent innovation is the inclusion of a close monitoring system, reporting on time, and digital information validation. These initiatives will exert trust between common people and insurers to develop confidence for stakeholders in the business for the long term. Alongside expanding market size and robust implementation of corporate governance guidelines is a must for the insurance sector (Islam, 2021). 
So, considering the above opportunities and limitations, it can be said that Bangladesh has tremendous potential to grow its life insurance market to the country's economic progress. Insurance companies must maintain efficient operational mechanisms and strong financial conditions. As a result, they can keep their promises and maintain good images. In Bangladesh, the life insurance market is mainly agent-driven, and studies showed that $80 \%$ of customers purchase the policy from them. Investment in a digital policy opening system will be a great move to reach all levels of customers. Companies should focus on virtual channels for recruiting, training and engaging their agents to improve the situation. Ultimately companies should always closely monitor the changing needs of customers and design their products accordingly. Improving the premium payment process by introducing a digital payment gateway, application to see the latest financial statement of the policy will attract the prospective policyholders and helps to build trust. Policyholders need insurance companies always to meet up expectations of fair and fast claims processing, while companies that get this right will engender customer loyalty and improve brand reputation (Mahmud, 2021).

This study mainly focuses on the influential critical aspects that drive a prospective policyholder's life insurance purchasing decision. The study aims to determine whether any relationship exists between demographic and socio-economic variables that affect the consumers' insurance purchasing decisions. The first part of the paper includes literature of similar research, and in the second part, frequency distribution analysis is discussed. After that, binary logistic model is applied to interpret the relation of insurance buying decisions with some demographic and socio-economic aspects. In the third section, findings and some recommending remarks will be included, and in the last segment, concluding remarks will be included with reference and appendix.

The study's findings will help the policymakers, companies, government, and regulators look into the crucial issue and take prompt positive action for the development of the life insurance sector in Bangladesh. This research will also help existing customers, and prospective life insurance customers understand and realize the benefit of having a life insurance policy.

\section{Literature Review}

The life insurance market in Bangladesh is very small compared to other neighboring developing countries. There are several reasons behind it. Life insurance, to some extent, is considered irrelevant or inappropriate. There is also a conflict in ideological, cultural, and religious perspectives taking an insurance policy. Many people think that financial security is provided through the family (Outreville, 1996).

It has been found that the demand for a life insurance policy is correlated with consumer's lifetime allocation process of resources. It is believed that each family has its own utility-maximization level compare to its degree of relative risk aversion. Although in some studies, it has been found that inter-country differences are likely 
to reflect differences in the degree of relative risk aversion and therefore affect the demand for life insurance (Yaari, 1965).

Some important socio-economic factors such as the age of the person, education level, and gender have an insignificant impact on prospective policyholders' minds while deciding on buying life insurance policy. The factors which greatly played on the mind of the policyholders are income level, profession, family size, which are also statistically significant. This research was conducted by (Namasivayam et al. 2006) on India's LIC (Life Insurance Company).

Lin and Chen (2006) investigates the influential factors that work as a catalyst on consumers' minds: country of origin of the company, product knowledge of the customer, and product involvement. They have found a significant relationship between the company's origin and financial literacy about insurance and product involvement that affect consumer's buying decision of life insurance policy.

Several information-bearing materials such as articles, institutions in risk management, and insurance research institutions have a significant impact that drives a consumer to buy a life insurance policy (Khurana, 2009). Websites have also played a great role while recommending quality life insurance companies for consumers (Mahajan, 2013).

The external economic environment has a crucial impact on driving customers' financial products purchasing behaviors. Another study reveals that salespersons' ethical sales attitude does play a crucial role in winning customer loyalty through converting customers trust, So customer trust in the company exerts more influence on customer loyalty than does customer trust in the salesperson, which has implications for the life insurance industry (Meinow, et al. 2005).

A study found that for people who live in the rural area aged 31-40 in that case, insurance agents were the most important source of motivation to decide whether they would buy an insurance policy. They used to collect relevant information about insurance from the agents too. Money back policy is quite popular with them. The study also reveals that rural people have less faith in the private insurance company. They trust more government-owned life insurance companies (Bodla and Verma, 2007).

People also purchase life insurance policy because to them it embarks a new opportunity to them for investing their money for a longer period additionally it will give them some added advantage like risk coverage against sudden death/ sudden accident, tax benefits, and also their post-retirement needs (Ray and Ali, 2008).

Leek et al. (2000) and Honkanen et al. (2006) observed that policy premium rate, value for money, and family income have no impact on insurance policy plans. They have also found that high prices had a negative impact on attitude toward consumption. Financial literacy has played a great influence on purchasing life insurance policies (Lewis, 1989).

Namasivayam et al. (2006) researched the socio-economic factors responsible for purchasing insurance found that sex, age, and educational level had no impact on purchasing life insurance policies. On the contrary, income level, occupation, and family size are major factors that significantly drive the prospective policyholders' 
minds while making purchasing decisions.

Reddy (2005) found that consumers feel at ease to have a policy in a private insurance company, but when it comes to the point of reliability and trust issue of the company, they are prone to rush in the state-owned insurance company.

The urban market is greatly influenced by product-based features like risk coverage, tax benefits, bonus, etc. while making alternative investment decisions like insurance. While the rural people are influenced by the non-product features like the agent's credibility, company's reputation, trust, customer service, company goodwill, and money back guaranty for purchasing life insurance policy (Athma and kumar, 2007).

Thakur et al. (2016) found that a large portion of the prospective customer of life insurance policy showed interest in insurance because it serves the need for higher risk coverage and also for the good return with safety.

Chowdhury et al. (2016) has identified six factors influencing policyholder behavior: customized and timely services, better company reputation, customer convenience, better service quality, tangible benefits, and effective customer relationship management.

In developing countries like Bangladesh and India, awareness and regulations for insurance are very weak. The empirical study reveals that most families' major financial needs are children's education and marriage expenses (Narender and Sampath, 2014).

A survey conducted in Nigeria found out the factors that enhance the purchasing decision of life insurance and found that company loyalty was a major concern influencing purchasing decision, and the company-client relationship stood as a last. A survey conducted in Bangladesh using Servqual Model found that people are more interested in private life insurance companies because of better service quality. Among local private, state-owned, and foreign company customers prefer foreign companies to have great operation experience and the wider area of coverage. They also found that $25 \%$ of the respondents have selected policy because of the great influencing power of the sales personnel (Yadav et al. 2012).

In Uttar Pradesh, India, a study was conducted by Singh(2014) and revealed that maximum people take policy for tax rebates and family safety purposes. He also found that major insurance products are child plans and pension plans. He even found that most people get insurance products directly from insurance agents, followed by banks, financial institutions, and brokers. It was found that government service members aged $26-45$ buy more insurance products, and the middle-income group buys more insurance policies.

\section{Methods}

This section consists of six sub-sections. The subsections are target groups, sampling techniques, data collection, and data analysis techniques.

\subsection{Target group}

In this study, data are collected solely from the primary source. A structured 
questionnaire was prepared to collect data for the study. Individuals, who were eligible for purchasing a life insurance policy, were targeted for the study.

\subsection{Instruments used in data collection}

The online Google Form questionnaire has been used to collect information from individuals in different places of Bangladesh to know the factors influencing their purchasing behavior of life insurance policy.

\subsection{Data collection}

A questionnaire was administered to the prospective policyholders of a life insurance policy. Respondents were selected based on the representative population who had at least the capacity to purchase a life insurance policy. Respondents had been reached through the author's contact, medium, social media groups, employment groups, and the students' families pursuing post-graduate degrees. This survey collected information for the study, such as demographic information (age, sex, education, income) and other related factors directly to the factors influencing purchasing consideration of life insurance.

Based on this data, concluding remarks will be drawn on whether the selected variables influence the prospective policyholders purchasing decision of life insurance policy or not.

\subsection{Sample size}

The convenience sampling technique has been used in this study. About five hundred respondents responded in this study. After verification, 378 respondents were selected for the study. A benchmark was chosen for the simplicity of calculating sample size. We have selected twenty thousand respondents as our benchmark.

Sample Size $=\frac{\frac{z^{2} * P(1-P)}{e^{2}}}{1+\left(\frac{z^{2} *(1-P)}{e^{2} * N}\right)}=\frac{\frac{1.96^{2} * .5(1-.5)}{.05^{2}}}{1+\left(\frac{1.96^{2} *(1-.05)}{.05^{2} * 15000}\right)}=375$

\subsection{Techniques of data analysis}

This study took the efforts to explore the influencing factors that work as a catalyst to purchase a life insurance policy by the prospective policyholder and current policyholders who had recently bought the policy. Descriptive analysis (e.g., frequency and percentage) was used in this study to find out the most influencing factors. The five-point Likert scale was used in this study to assess the respondent's opinions on the demographic and socio-economic factors that affect insurance policy purchasing decisions. Respondents were asked to provide their opinion in 
five statements; the likert scale has been used to show a series of attitudes toward each variable, given numerical values ranging from Strongly Agree to Disagree Strongly. Ratings are on 5-point scale $(5=$ strongly agree, $4=$ agree, $3=$ neutral, $2=$ disagree, $1=$ strongly disagree). Other information is coded for 'Yes' (1) and 'No' coded for (0). In other categorical responses are coded (1-5) ranges for the simplicity of the study.

The binary logistic regression is appropriate when the dependent variable is dichotomous (Mahmud et al. 2014). This study used binary logistic regression because the dependent variable "decision on adopting/purchasing life insurance policy" had two categories. "It influences the consumers to purchase life insurance policy" was coded as "one," and "It does not influence the consumers to purchase life insurance policy" was coded as "zero." The researchers also used logistic regression to assess respondents' opinions on various socio-economic issues such as financial and social empowerment status (Mahmud et al. 2014).

The model can be specified as:

$$
\begin{aligned}
{\left[\frac{P_{i}}{1-P_{i}}\right]=A_{0} } & +b_{1} X_{1}+b_{2} X_{2}+b_{3} X_{3}+b_{4} X_{4}+b_{5} X_{5}+b_{6} X_{6}+b_{7} X_{7}+b_{8} X_{8} \\
& +b_{9} X_{9}+b_{10} X_{10}+b_{11} X_{11}+b_{12} X_{12}+b_{13} X_{13}+b_{14} X_{14}+b_{15} X_{15} \\
& +b_{16} X_{16}+\mu
\end{aligned}
$$

Where,

$P_{i} \quad=$ It influences the consumers to purchase a life insurance policy

$1-P_{i}=$ It does not influence the consumers to purchase a life insurance policy

$X_{1}=$ Having prior policy

$X_{2}=$ Socially aware of life insurance

$X_{3}=$ purchase due to Covid-19 outbreak

$X_{4}=$ Purchase for financial protection

$X_{5}=$ Source of policy information

$X_{6}=$ Insurance literacy

$X_{7}=$ Attitude towards life insurance

$X_{8}=$ Purpose of life insurance

$X_{9}=$ Agents influence

$X_{10}=$ Investment purpose

$X_{11}=$ Employers provide health insurance

$X_{12}=$ Monthly Medical expense

$X_{13}=$ Number of dependent

$X_{14}=$ Monthly income

$X_{15}=$ Nature of work

$X_{16}=$ Age

$X_{17}=$ Gender

And, $\mu=$ error term of the equation one 


\section{Data analysis}

4.1 Demographic and socio-economic characteristics of the prospective life insurance policyholders

Table 1: Frequency distribution of the variables

\begin{tabular}{|c|c|c|c|}
\hline \multirow{2}{*}{$\begin{array}{c}\text { Variable } \\
\text { Name }\end{array}$} & \multirow[t]{2}{*}{ Category } & \multicolumn{2}{|c|}{ Responses } \\
\hline & & Number & Percentage \\
\hline \multirow[t]{2}{*}{ Gender } & Male & 251 & 66.40 \\
\hline & Female & 127 & 33.60 \\
\hline \multirow[t]{4}{*}{ Age } & $20-29$ & 274 & 72.49 \\
\hline & $30-39$ & 29 & 7.67 \\
\hline & $40-49$ & 32 & 8.47 \\
\hline & 50-60 and above & 43 & 11.36 \\
\hline \multirow[t]{3}{*}{ Education } & Graduation & 146 & 38.62 \\
\hline & Post-graduation & 119 & 31.48 \\
\hline & Other & 113 & 29.89 \\
\hline \multirow{5}{*}{$\begin{array}{l}\text { Nature of } \\
\text { work }\end{array}$} & Agriculture & 72 & 19.05 \\
\hline & Government job & 49 & 12.96 \\
\hline & Business & 39 & 10.32 \\
\hline & Private organization & 192 & 50.79 \\
\hline & NGO & 26 & 6.88 \\
\hline \multirow{5}{*}{$\begin{array}{l}\text { Monthly } \\
\text { income }\end{array}$} & Tk. 15000 & 218 & 57.67 \\
\hline & Tk. 25500 & 43 & 11.38 \\
\hline & Tk. 35500 & 46 & 12.17 \\
\hline & Tk. 45500 & 22 & 5.82 \\
\hline & Tk. 65000 and above & 49 & 12.96 \\
\hline \multirow{4}{*}{$\begin{array}{l}\text { Number of } \\
\text { dependent in } \\
\text { the family }\end{array}$} & 1 person & 93 & 24.60 \\
\hline & 2 persons & 76 & 20.11 \\
\hline & 3 persons & 79 & 20.90 \\
\hline & 4 and above & 130 & 34.39 \\
\hline \multirow{4}{*}{$\begin{array}{l}\text { Monthly } \\
\text { medical } \\
\text { expense }\end{array}$} & Tk. 750 & 102 & 26.98 \\
\hline & Tk. 1000 & 41 & 10.85 \\
\hline & Tk. 1500 & 91 & 24.07 \\
\hline & Tk. 5000+ & 144 & 38.10 \\
\hline \multirow{2}{*}{$\begin{array}{l}\text { Employers } \\
\text { Insurance }\end{array}$} & Yes & 78 & 20.63 \\
\hline & No & 300 & 79.37 \\
\hline
\end{tabular}




\begin{tabular}{|c|c|c|c|}
\hline \multirow{5}{*}{$\begin{array}{c}\text { Investment } \\
\text { purpose }\end{array}$} & Strongly Agree (SA) & 162 & 42.86 \\
\hline & Agree (A) & 108 & 28.57 \\
\hline & Neutral (N) & 40 & 10.58 \\
\hline & Disagree (D) & 51 & 13.49 \\
\hline & Strongly Disagree (SD) & 17 & 4.50 \\
\hline \multirow{5}{*}{$\begin{array}{c}\text { Source of } \\
\text { Policy } \\
\text { Information }\end{array}$} & Newspaper & 136 & 35.98 \\
\hline & Television & 67 & 17.72 \\
\hline & Hospitals & 43 & 11.38 \\
\hline & Social Media & 69 & 18.25 \\
\hline & Agents & 63 & 16.67 \\
\hline \multirow{5}{*}{$\begin{array}{l}\text { Tax benefit } \\
\text { purpose }\end{array}$} & Strongly Agree (SA) & 142 & 37.57 \\
\hline & Agree $(A)$ & 54 & 14.29 \\
\hline & Neutral (N) & 131 & 34.66 \\
\hline & Disagree (D) & 6 & 1.59 \\
\hline & Strongly Disagree (SD) & 45 & 11.90 \\
\hline \multirow{5}{*}{$\begin{array}{c}\text { Negative } \\
\text { Attitude } \\
\text { Towards } \\
\text { Life } \\
\text { Insurance }\end{array}$} & Strongly Agree (SA) & 104 & 27.51 \\
\hline & Agree (A) & 115 & 30.42 \\
\hline & Neutral (N) & 32 & 8.47 \\
\hline & Disagree (D) & 115 & 30.42 \\
\hline & Strongly Disagree (SD) & 12 & 3.17 \\
\hline \multirow{2}{*}{$\begin{array}{c}\text { Insurance } \\
\text { literacy }\end{array}$} & Yes & 232 & 61.38 \\
\hline & No & 146 & 38.62 \\
\hline \multirow{5}{*}{$\begin{array}{c}\text { Policy } \\
\text { Information }\end{array}$} & Strongly Agree (SA) & 8 & 2.12 \\
\hline & Agree (A) & 117 & 30.95 \\
\hline & Neutral $(\mathrm{N})$ & 163 & 43.12 \\
\hline & Disagree (D) & 64 & 16.93 \\
\hline & Strongly Disagree (SD) & 26 & 6.88 \\
\hline \multirow{5}{*}{$\begin{array}{l}\text { Financial } \\
\text { Protection }\end{array}$} & Strongly Agree (SA) & 14 & 3.70 \\
\hline & Agree (A) & 160 & 42.33 \\
\hline & Neutral (N) & 122 & 32.28 \\
\hline & Disagree (D) & 66 & 17.46 \\
\hline & Strongly Disagree (SD) & 16 & 4.23 \\
\hline \multirow{5}{*}{$\begin{array}{c}\text { Due to } \\
\text { Covid-19 }\end{array}$} & Strongly Agree (SA) & 40 & 10.58 \\
\hline & Agree (A) & 115 & 30.42 \\
\hline & Neutral $(\mathrm{N})$ & 67 & 17.72 \\
\hline & Disagree (D) & 98 & 25.93 \\
\hline & Strongly Disagree (SD) & 58 & 15.34 \\
\hline
\end{tabular}




\begin{tabular}{|c|c|c|c|}
\hline \multirow{2}{*}{$\begin{array}{c}\text { Social } \\
\text { awareness }\end{array}$} & No & 30 & 7.94 \\
\cline { 2 - 4 } & Yes & 348 & 92.06 \\
\hline \multirow{2}{*}{ Prior Policy } & Yes & 34 & 8.99 \\
\cline { 2 - 4 } & No & 344 & 91.01 \\
\hline \multirow{2}{*}{$\begin{array}{c}\text { Purchase } \\
\text { policy }\end{array}$} & No & 133 & 35.19 \\
\cline { 2 - 4 } & Yes & 245 & 64.81 \\
\hline
\end{tabular}

In this study, the demographic features of the respondents reveal that there are $66.4 \%$ of persons are male, and only $33.60 \%$ are female. Among them, more than $72 \%$ belong to the 20-30 age range category. Most of the respondents have graduation and post-graduation degrees and pursue the private-sector job. About $57 \%$ of the respondents have a monthly salary of Tk. 15,000. Most of the families have more than four dependent members in their family and $38 \%$ of the families spend more than Tk.5000 in a month as their medical expenses.

In Bangladesh, employers' insurance is not quite popular till now. In this study, it has been seen that only $20 \%$ of the respondents enjoy the employer's health insurance.

While interpreting the socio-economic variables of the study, it has been observed that the majority of the persons are willing to take life insurance policy as a tool for their long-term investment purpose, enjoying tax benefits and for the protection of their family members. A significant number of consumers get insurance-related information from newspapers, television, and social media. The study also reveals that a significant improvement is seen in the case of financial literacy about insurance. About $61 \%$ of the respondents answered that they had basic knowledge about the insurance policy. But there is a great concern that the majority of them have shown a negative attitude towards insurance. As the study is conducted during the covid-19 situation, respondents were asked to give their true opinion on whether covid-19 impacts their policy purchase decision and they showed neutral opinions. Only $8 \%$ of the respondents have already purchased life insurance policy. Respondents are also asked whether they will purchase life insurance policy shortly or not, and $65 \%$ of them showed interest in purchasing it, and 35\% did not show any interest.

In the study, the main objective is whether those mentioned above demographic and socio-economic factors impact the purchasing decision of life insurance policy consumers in Bangladesh. 
Factors Shaping Consumers Intention in Purchasing Life Insurance Policy in...

4.2 Factors influencing the consumer's choice of purchasing life insurance policy

Table 2: The outcomes of the binary logistic model

\begin{tabular}{|c|c|c|c|c|}
\hline Variables & Coefficient & $\begin{array}{c}\text { Level of } \\
\text { Significance }\end{array}$ & Odds Ratio & Probability \\
\hline Constant & 1.444116 & 0.197 & 4.238106 & \\
\hline $\begin{array}{l}\text { Having Prior } \\
\text { Policy }\end{array}$ & -.2525863 & 0.586 & .7767892 & \\
\hline Social Awareness & .6572799 & 0.130 & 1.929537 & \\
\hline Due to Covid-19 & -.10368 & 0.286 & .9015137 & \\
\hline $\begin{array}{c}\text { Financial } \\
\text { Protection }\end{array}$ & .289006 & 0.301 & .7490077 & \\
\hline $\begin{array}{c}\text { Policy } \\
\text { Information }\end{array}$ & -.5078333 & 0.000 & .6017981 & .376 \\
\hline $\begin{array}{c}\text { Insurance } \\
\text { Literacy }\end{array}$ & .0668058 & 0.042 & 1.069088 & .517 \\
\hline $\begin{array}{l}\text { Attitude Towards } \\
\text { Life Insurance }\end{array}$ & .2952916 & 0.079 & 1.343518 & \\
\hline $\begin{array}{c}\text { Tax Benefit } \\
\text { Purpose of life } \\
\text { insurance }\end{array}$ & .2029447 & 0.025 & .8163234 & .449 \\
\hline Agents Influence & -.1113225 & 0.155 & .8946502 & \\
\hline $\begin{array}{l}\text { Investment } \\
\text { purpose }\end{array}$ & .1450502 & 0.296 & 1.156098 & \\
\hline $\begin{array}{l}\text { Employers } \\
\text { Insurance }\end{array}$ & .1237845 & 0.694 & 1.131772 & \\
\hline $\begin{array}{l}\text { Monthly Medical } \\
\text { Expense }\end{array}$ & -.0000586 & 0.363 & .9999414 & \\
\hline No. of Dependent & .0525086 & 0.045 & .9488462 & .487 \\
\hline Monthly Income & .052508 & 0.012 & 1.000022 & .500 \\
\hline Nature of Work & .2319441 & 0.023 & 1.261049 & .558 \\
\hline Education & -.0258487 & 0.860 & .9744825 & \\
\hline Age & -.00045 & 0.971 & .9995501 & \\
\hline Gender & .3886174 & 0.144 & 1.47494 & \\
\hline \multicolumn{5}{|c|}{$\begin{array}{l}\text { Pseudo R2=0.3971 } \\
\text { Note: Probability= }[\text { odd } /(1+\text { odd })]\end{array}$} \\
\hline
\end{tabular}


In this study, efforts are given to find out the factors that greatly influence the purchasing decision of life insurance policy. The study's outcome will help the policymakers and other stakeholders of the life insurance industry emphasize the key areas of improvement. As a result, they can attract more life insurance policyholders to their portfolios. Consumers will be benefited by getting desired services from the other party.

Several factors have been analyzed to predict the influential item that drives consumers' minds while purchasing any financial products like life insurance policy. In this study eighteen, demographic and socio-economic variables have been analyzed. Among them, only six variables have been found statistically significant. According to the above estimation, there is no significant relation of the demographic variable education, age, and gender with the consumer's willingness to purchase life insurance policy. This study also reveals no significant impact of agents influence, monthly medical expense, and arrangements of the employer's health insurance facility with the purchasing insurance decision of the consumers, as the study conducted during the covid-19 period, though there is no significant relation with the dependent variable. This study also didn't find any significant relationship between the consumers' prior life insurance policy, social awareness of the consumers, and attitude towards life insurance policy. Additionally, it has been seen that consumers did not prioritize insurance as an alternative means of investment.

This study reveals a negative association between consumers' access to information and purchasing life insurance policies. It is because of in Bangladesh; negative information spreads more. Almost in every print, electronic, and social media, negative news of insurance companies is published. So ultimately, consumers bear a negative mindset about purchasing life insurance policies against the perceived information they have received. There is a $37 \%$ probability that consumer's access to information influenced the policy purchase decision negatively.

Insurance literacy has a positive influence on the consumer's buying decision of life insurance policy. People who are aware of the life insurance policy's benefits have a positive mindset about life insurance policy. So it is important for the policymakers to literate mass people and builds awareness through different public and private initiatives.

This study also reveals that consumers are also willing to purchase life insurance policies because of the tax rebate policy. This item is statistically significant and has a $44.9 \%$ influence on the policy purchase decision. In Bangladesh, taxpayers enjoy tax rebate facilities on the premium amount paid for life insurance policy. There is a $48 \%$ probability that if the Number of dependent members in the family increases, prospective policyholders show interest in purchasing life insurance policies. Families usually take policy for future financial stability and other crucial causes like children's education and marriage.

There is a significant relationship between respondents' monthly income and decision on purchasing life insurance policy. There is a 50\% probability of this variable which has a significant influence on the dependent variable. This study also 
reveals that the professional patterns of the consumers are also a good indicator of demanding life insurance policy. In our survey, it has been seen that the majority of the respondents are private service holders. They are often much serious about their lifestyle and quality of life.

\subsection{Diagnostic test}

In binary logistic regression, the goodness of fit of the model 'GOF' test is used whether the selected model is appropriate or not. The null hypothesis is that the selected model is appropriate, and the alternative hypothesis is that the selected model is not appropriate. Based on the estimated result, the chi ${ }^{2}$ value is 369.05 , which is not statistically insignificant. So we can conclude that the null hypothesis is accepted to say that the selected model is good and appropriate for this type of study.

Table 3: Goodness of fit test

\begin{tabular}{|c|c|}
\hline Logistic model for PURCHASEPOLICY, goodness-of-fit test \\
\hline number of observations & 378 \\
\hline number of covariate patterns & 372 \\
\hline Pearson chi2(353) & 369.05 \\
\hline Prob $>$ chi2 & 0.2676 \\
\hline
\end{tabular}

\section{Conclusion}

The inclusion of mass people under life insurance coverage is inevitable to achieve the sustainable development goal by Bangladesh within 2030. Life insurance policy gives assurance against accidental death or a source of long-term investment. It also contributes to the GDP and infrastructural development of a country. This study highlights such factors that can be a great clue for the insurer to market and reach their prospective customers. This study will also be beneficial for the consumers to understand the benefits of purchasing life insurance. This study was done using a binary logistic model using data from three seventy-eight respondents. The study reveals that some demographic characteristics like number of dependent members in the family, the monthly income of the customer, and nature of work positively influence customers' insurance policy purchase decisions. In addition, insurance literacy and tax benefit purpose also positively impact the policy purchase decision. On the other hand, information about life insurance has a negative impact on customers buying decisions. In Bangladesh in earlier times, insurance companies were not tightly monitored, and a lack of digitization was not introduced. News of refusing claims, lack of timely settlement of claims and other issues, and the agents' dishonesty drew negative attention about life insurance. Nowadays, the insurance regulatory authority has taken some prudent steps to improve the situation. This study was conducted on limited selected demographic and socio-economic characteristics due to lack of time. Further studies can be done using broad 
demographic and socio-economic characteristics. This study will be helpful to the prospective policyholders, insurers, government to look into the results and use them as motivating factors to bring more people under life insurance coverage.

\section{References}

[1] Abeda, R. (2019). “Life insurance - a 'sunrise industry' in Bangladesh". [online] The Financial Express. 29 October 2019

[2] Ahmed, A. (2013). "Perception of Life Insurance Policies in Rural India". Kuwait Chapter of the Arabian Journal of Business and Management Review 2: 17

[3] Athma, P. and Kumar, R. (2007). "An explorative study of life insurance purchase decision making": influence of product and non-product factors. ICFAI journal risk \& insurance 6: 19-21.

[4] Bb.org.bd.(2021). Bangladesh Bank. [online] Available at: <https://www.bb.org.bd/en/index.php/financialactivity/insurance> [Accessed 18 September 2021].

[5] Bodla, B.S. and Verma, S. R. (2007). "Life Insurance Policies in Rural Area: Understanding Buyer Behavior", The ICFAI Journal of Services Marketing, Vol. V, No. 4, pp. 18-27.

[6] Chowdhury, T., Rahman, M. and Afza, S. (2016). "Perceptions Of The Customers' Towards Insurance Companies In Bangladesh", BRAC University Journal, Vol. IV, No. 2, 2007, pp. 55-66

[7] Honkanen, P., Verplanken, B. and Olsen, S.O. (2006). " Ethical values and motives driving organic food choice". Journal of Consumer Behaviour 5: 420430

[8] Islam, F. (2021). "How life insurers can thrive in the new normal". [online] Dhaka Tribune. Available at:

<https://www.dhakatribune.com/business/2021/08/04/how-life-insurers-canthrive-in-the-new-normal> [Accessed 18 September 2021].

[9] Khurana, S. (2009). "Customer Preferences in Life Insurance Industry in India", The Icfai University Journal of Services Marketing, Vol. VI, No.3, pp. 6068.

[10] Mahajan, K. (2013). “Analysing Consumer Decision Making Process in Life Insur-ance Services". International Journal of Marketing, Financial Services \& Manage-ment Research, 2, 60-68.

[11] Ala Ahmad. (2021). Bangladesh's insurance industry outlook for 2021 | MetLife Insurance Bangladesh. [online] Available at:

$<$ https://www.metlife.com.bd/blog/insurance/bangladesh-insurance-industryoutlook-2021/> [posted: 30-01-2021].

[12] Lewis, F.D. (1989). "Dependents and the demand for life insurance". The American Economic Review 79: 452-467. 
[13] Meinow, B., Kareholt, I. and Lagergren, M. (2005). "According to need? Predicting the amount of municipal home help allocated to elderly recipients in an urban area of Sweden”. Heal. Soc. Care Community, 13(4), 366-377.

[14] Namasivayam, N., Ganesan, S. and Rajendran, S. (2006). "Socioeconomic Factors Influencing the Decision in Taking Life Insurance Policies", Insurance Chronicle, August, The Icfai University Press, pp. 6570.

[15] Narender, S. and Sampath, L. (2014). "Consumer Awareness towards Life Insurance Sector in India". Abhinav International Referred Journal of Research in Management and Technology, 3, 45-51.

[16] Leek, S., Maddock, S. and Foxall, G. (2000). "Situational determinants of fish consumption". British food journal 102: 18-39.

[17] Outreville, J. F., (1996). "The Relationship Between Insurance, Financial Development and Market Structure in Developing Countries", UNCTAD Review, 3: 53-69.

[18] Ray, Subhasis and Ali, Shahid (2008). "Gap Analysis Between Customer's Expectation and Current Provisions of Indian Life Insurance Industry", The Icfai Universit Journal of Consumer Behavior, Vol. III, No.3, pp. 33-46.

[19] Reddy, G. S. (2005). "Customer perception towards private life insurance companies' policies with reference to Bangalore city". Indian Journal of Marketing 35: 913.

[20] Ali, M. and Mahmud, S.U. (2021). "Insurance penetration in Bangladesh fell in 2020". [online] The Business Standard. Available at:

https://www.tbsnews.net/economy/insurance-penetration-bangladesh-fell2020-286696.

[21] Singh, H. (2014). “An Empirical Study of Life Insurance Consumer's Behaviour in Uttar Pradesh", An Internationally Indexed Refereed Research Journal \& A complete Periodical dedicated to Humanities \& Social Science Research, Half Yearly Vol-5, Issue-1, pp 1-7

[22] Thakur, I. and Nigam, A. (2016). "A Study Of Factors Affecting Customer's Investment Towards Life insurance Policies", AltiusShodh Journal of Management and Commerce.

[23] Yaari, M. (1965). "Uncertain Lifetime, Life Insurance and the Theory of the Consumer", Re-view of Economic Studies, 32: 137-150.

[24] Yadav, M. and Tiwari, D. (2012). "A study on factors affecting customer's investment towards life insurance policies". International Journal of Marketing, Financial Services and Management Research 1: 106-123.

[25] Lin, L.Y. and Chen, C. S. (2006). "The influence of the country-of-origin image, product knowledge and product involvement on consumer purchase decisions: an empirical study of insurance and catering services in Taiwan", Journal of Consumer Marketing, Vol. 23 Issue: 5 
Ramij

\section{Appendix}

Table 4: Correlation matrix

\begin{tabular}{|c|c|c|c|c|c|c|c|c|c|c|c|c|c|}
\hline & GEN & AGE & EDU & EMP & INC & NODEPEN & MEDEXP & ORGHEA H & INFO & KEYREA N & REASON $\sim T$ & KNOWLE E & SCHEME 0 \\
\hline GEN & 1.0000 & & & & & & & & & & & & \\
\hline AGE & 0.3408 & 1.0000 & & & & & & & & & & & \\
\hline EDU & -0.0278 & 0.2109 & 1.0000 & & & & & & & & & & \\
\hline EMP & -0.0920 & -0.1818 & 0.0320 & 1.0000 & & & & & & & & & \\
\hline INC & 0.0611 & 0.0673 & -0.0185 & -0.4276 & 1.0000 & & & & & & & & \\
\hline NODEPEN & 0.0396 & 0.0178 & 0.0699 & -0.0294 & 0.0068 & 1.0000 & & & & & & & \\
\hline MEDEXP & -0.0110 & -0.0340 & -0.0184 & -0.0908 & 0.3194 & 0.0443 & 1.0000 & & & & & & \\
\hline ORGHEALTH & -0.0387 & -0.0813 & 0.0144 & -0.0412 & 0.0657 & 0.0058 & -0.0110 & 1.0000 & & & & & \\
\hline INFO & -0.0639 & -0.1091 & 0.0051 & 0.0416 & -0.0098 & 0.0155 & 0.0166 & 0.0760 & 1.0000 & & & & \\
\hline KEYREASON & 0.1265 & 0.0576 & -0.0394 & 0.0203 & 0.1272 & -0.0242 & 0.0323 & 0.0594 & 0.0618 & 1.0000 & & & \\
\hline REASONNOT & -0.1141 & -0.0690 & -0.0091 & 0.0233 & -0.0473 & -0.0332 & -0.0116 & 0.0230 & 0.0697 & -0.0126 & 1.0000 & & \\
\hline KNOWLEDGE & 0.1041 & -0.0114 & -0.0545 & -0.1805 & 0.1853 & 0.0434 & 0.1558 & 0.0117 & -0.0442 & 0.0681 & -0.0324 & 1.0000 & \\
\hline SCHEMEINFO & -0.0105 & -0.0712 & 0.0299 & 0.0167 & 0.1526 & 0.0486 & -0.0387 & -0.0750 & -0.1243 & -0.0680 & -0.0125 & -0.0382 & 1.0000 \\
\hline OPINIONOFH H & 0.0106 & -0.0077 & -0.0307 & -0.0101 & 0.1150 & 0.1347 & 0.1203 & -0.0454 & 0.0295 & -0.0752 & -0.0360 & 0.0631 & 0.3120 \\
\hline CONCIOUSCO D & -0.0072 & -0.1151 & -0.0721 & 0.0141 & 0.0169 & -0.0692 & 0.0216 & -0.1237 & -0.0175 & 0.0019 & -0.0669 & 0.0931 & 0.1919 \\
\hline SOCIALAWAR & -0.0224 & 0.0233 & 0.0640 & 0.0203 & -0.0547 & -0.0316 & -0.0112 & 0.0530 & -0.0413 & -0.0462 & -0.0366 & -0.0887 & -0.1749 \\
\hline & OPINIO H & ONCIO D & SOCIAL R & & & & & & & & & & \\
\hline OPINIONOFH H & 1.0000 & & & & & & & & & & & & \\
\hline CONCIOUSCO D & 0.1548 & 1.0000 & & & & & & & & & & & \\
\hline SOCIALAWAR & -0.1916 & -0.2206 & 1.0000 & & & & & & & & & & \\
\hline
\end{tabular}

